\title{
SEGMENTASI CITRA THORAX PARU-PARU MANUSIA DARI SINAR-X MENGGUNAKAN METODE KONTUR AKTIF
}

\author{
Zulkarnain, Sinta Syaputri* \\ Jurusan Fisika, Fakultas Matematika dan Ilmu Pengetahuan Alam, Universitas Riau, Kampus Bina Widya \\ J1. Prof. Muchtar Luthfi Pekanbaru, 28293, Indonesia \\ "e-mail: sinthasyaputri@gmail.com
}

\begin{abstract}
ABSTRAK
Penelitian terhadap objek citra medis yang berupa citra paru-paru x-ray thorax semakin banyak dikembangkan, karena informasi yang terkandung dalam citra medis digunakan untuk menganalisa dan mengetahui bentuk dari paru-paru. Diperlukan proses normalisasi dan perbaikan citra dan dilanjutkan dengan proses segmentasi dengan menggunakan metode yang tepat. Metode kontur aktif snake digunakan karena tahan terhadap noise yang ada di sekitar objek. Penelitian telah dilakukan dengan menggunakan program GUI software matlab versi R2015a. Citra melalui tahap awal preprocessing yaitu dikonversi menjadi citra grayscale. Proses segmentasi dilakukan setelah proses inisialisasi berupa kurva lingkaran kecil yang diletakkan di bagian objek yang akan disegmentasi dan penentuan parameter aktif kontur. Penentuan nilai parameter-parameter aktif kontur sangat berpengaruh terhadap hasil segmentasi dan mempengaruhi arah pergerakan aktif kontur. Apabila posisi koordinat aktif kontur berada diluar area yang akan disegmentasi maka akan menyebabkan aktif kontur menjauh dari objek tersebut. Validasi Tingkat akurasi hasil segmentasi dilakukan dengan membandingkan hasil segmentasi kontur aktif snake terhadap hasil segmentasi manual yaitu dengan metode MSE.
\end{abstract}

Kata Kunci: Segmentasi Aktif Kontur; Paru-paru X-Ray thorax; MSE.

\section{ABSTRACT}

[Title: Segmentation Of The Human Lung Thorax Image From X-Rays By Active Contour Method] Research on medical image objects in the form of lung images of thoracic X-Ray is increasingly being developed because the information contained in medical images is used to analyze and determine the shape of the lungs. The process of normalization and image improvement is needed and continued with the segmentation process using the right method. The active snake contour method is used because it is resistant to the noise around the object. The research has been used the Matlab software GUI program version R2015a. The image through the initial preprocessing stage is converted into a grayscale image. The segmentation process used after the initialization process in the form of a small circle curve placed of the object to be segmented and the determination position of the active contour or detemination of the active parameters of the contour. Determination of the value active contour parameters greatly influences the results of segmentation and influences the direction of active contour movement. If the active coordinate position of the contour is outside the area to be segmented it will cause active contours to move away from the object. Validation the level of accuracy of segmentation results is done by comparing the results of the snake active contour segmentation to the results of manual segmentation used MSE method.

Keywords: Active Contour Segmentation; Lung x-ray thorax; MSE. 


\section{PENDAHULUAN}

Citra medis (medical imaging) adalah suatu teknik atau proses penggambaran bagian-bagian organ tubuh dengan tujuan mengetahui kerusakan yang terdapat pada organ tubuh tersebut akibat aktivitas bakteri dan virus. Citra medis yang dimaksud di dalam penelitian ini adalah berkaitan dengan citrasinar-X.Pemeriksaan yang dapat dilakukan pada pesawat sinar-X salah satunya yaitu bagian thorax. Citra X-Ray thorax merupakan citra yang menampilkan penampang organ tubuh bagian dalam manusia khususnya pada bagian thorax (rongga dada) (Proklamasi, 2013). Salah satu pengolahan citra dikenal sebuah istilah segmentasi. Segmentasi merupakan teknik untuk membagi citra menjadi beberapa daerah (region) pada setiap daerah memiliki kemiripan atribut antara lain: tingkat keabuan (grayscale), tekstur (texture), warna (color), dan gerakan (motion). Salah satu metode segmentasi yaitu active contour atau kontur aktif yangbaik digunakan untuk segmentasi citra medis dikarenakan tahanterhadap noise yang ada di sekitar objek, sehingga bentuk objek yang diamati pada citra medis tertentu akan ditemukan.

Kontur aktifsebagai sekumpulan titik koordinat terkontrol pada konturdimana parameternya didefinisikan sebagai berikut.

$$
\mathcal{V}(s)=(x(s), y(s))
$$

dimana $x(s)$ dan $y(s)$ adalah koordinat $x$ dan $y$ pada kontur dan $S$ adalah indeks normalisasi dari titik kontrol (Evelyn, 2019).

\section{METODE}

Penelitian ini terbagi dalam dua tahapan, pertama dilakukan pengambilan data citra dan rekam medis menggunakan pesawat sinar-X Shimadzu Rad Speed di Instalasi Radiologi dan Radiodiagnostik Tahapan kedua yaitu pengolahan data citra medis menggunakan aplikasi MATLAB R2015a.Data yang didapatkan dari pesawat sinar-X diolah dengan menggunakan program berupa sitem GUI. Merancang dan membuat diawali dengan pembuatan flowchart terlebih dahulu agar pengolahan data dapat dilakukan secara sistematis.

Proses preprocessingdilakukan sebelum tahap segmentasi.Proses ini merupakan kumpulan dari proses yang digunakan untuk dapat menghasilkan segmentasi yang terbaik. Preprocessing yang digunakan adalah konversi dan perbaikan citra (Image Enhancement). Proses konversi citra dilakukan dari citra RGB menjadi citra grayscale (gambar yang memiliki tingkat warna keabuan). Proses kedua yaitu perbaikan citra, dalam hal ini menggunakan filter atau tapis gaussian untuk menghaluskan citra dan mengurangi noise atau derau pada citra. Proses di atas dapat memudahkan dalam hal segmentasi dengan menggunakan kontur aktif. Langkah selanjutnya adalah proses inisialisasi kurva.

Bagan alir program dapat dilihat pada Gambar 1. Langkah pertama yang dilakukan adalah melakukan inisialisasi kurva apabila citra tersebut telah melalui proses preprocessing. Kurva inisialisasi berbentuk lingkaran kecil dimana setiap lingkaran tersebut diletakkan di bagian objek yang kan disegmentasi khususnya pada bagian paru-paru. Tahap selanjutnya memberikan nilai iterasi pada objek tersebut agar proses segmentasi bisa berjalan dan mendeteksi tepian dari gambar atau objek yang ingin disegmentasi. Hasil dari segmentasi tersebut kemudian menjadi citra biner karena dapat memudahkan proses perbandingan antara hasil segmentasi manual paru-paru dengan hasil segmentasi menggunakan kontur aktif.

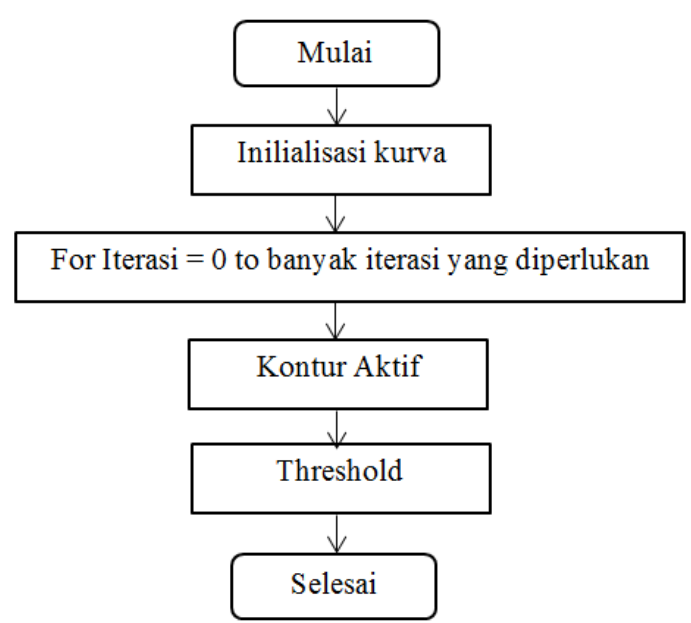

Gambar 1. Diagram alir program kontur aktif

Proses pembuatan program dilanjutkan dengan pembuatan program validasi. Validasi yang digunakan pada penelitian ini adalah validasi dengan metode MSE.Validasi Tingkat akurasi hasil segmentasi dilakukan dengan membandingkan hasil segmentasi kontur aktif snake terhadap hasil segmentasi manual (Michael, 1988).

\section{HASIL DAN PEMBAHASAN Pengujian Metode Kontur Aktif}

Pada penelitian ini dilakukan pengujian sistemdengan pengaruh parameter-parameter kontur 
aktif terhadap hasil segmentasi. Pengujian ini bertujuan untuk mengetahui kinerja dari algoritma kontur aktif Snake dalam melakukan proses segmentasi. Hasil pengujian dengan mengubah-ubah nilai parameter aktif kontur dapat dilihat pada Gambar 2.

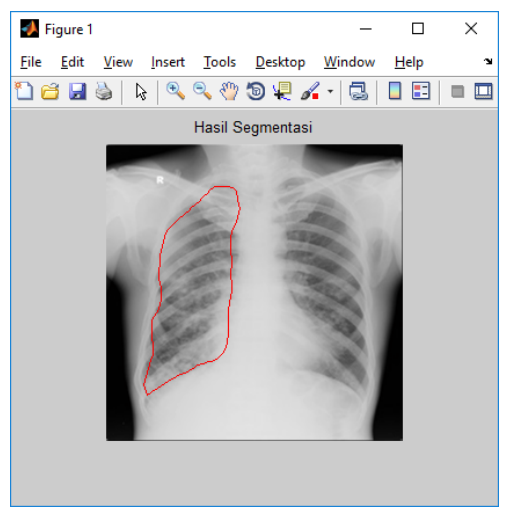

Gambar 2. Citra Img0208

Dimana secara visual terlihat bahwa garis merah kontur aktif mampu mendeteksi lekukan-lekukan pada paru-paru sebelah kiri. Perubahan nilai iterasi menjadi lebih besar mempengaruhi lama pergerakan kontur aktif dan waktu komputasi yang dibutuhkan untuk proses segmentasi.

\section{Validasi MSE}

Pengujian tingkat akurasi hasil segmentasi kontur aktif terhadap hasil segmentasi manual dengan menggunakan metode nilai MSE dapat dilihat pada Gambar 3.

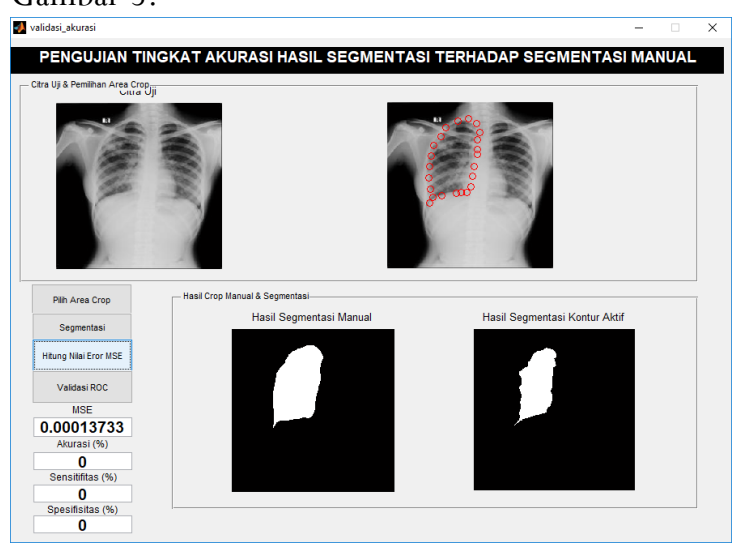

Gambar 3. Hasil pengujian tingkat akurasi dengan nilai MSE

Berdasarkan gambar di atas terlihat bahwa nilai MSE yang diperoleh untuk pengujian yang dilakukan adalah 0.00013733. Kecilnya nilai MSE menunjukkan bahwa hasil segmentasi kontur aktif memiliki eror yang sangat kecil atau dengan kata lain hasil segmentasi kontur aktif mendekati hasil segmentasi manual. Semakin besar nilai MSE maka akan semakin jauh hasil segmentasi kontur aktif dari hasil segmentasi manual (Proklamasi, 2013).

\section{KESIMPULAN}

Hasil segmentasi citra paru-paru menggunakan kontur aktif sangat dipengaruhi oleh nilai-nilai parameter kontur aktif. Nilai-nilai parameter kontur aktif bersifat eksperimental dan mempengaruhi nilai validasi MSE.Semakin besar nilai MSE maka akan semakin jauh hasil segmentasi kontur aktif dari hasil segmentasi manual. Begitu juga sebaliknya apabila nilai MSE semakin kecil maka akan semakin dekat hasil segmentasi kontur aktif dari hasil segmentasi manual.

\section{DAFTAR PUSTAKA}

Evelyn CP. 2009.Anatomi dan Fisiologi untuk Paramedis. Jakarta: PT Gramedia.

Michael Kass et all. 1988. Snake: Active Contour Models, International Journal of Computer Vision. Kluwer Academic Publisher: 321-331.

Proklamasi, Bara. 2013. Segmentasi Tulang Selangka pada Citra X-Ray Thorax dengan Menggunakan Metode Active Contour. Skripsi. Universitas IslamNegeri Maulana Malik Ibrahim Malang. 